\title{
Studies on the Exaggerated Natriuretic Response to a Saline Infusion in the Hypothyroid Rat
}

\author{
Edward W. Holmes, Jr., and Vincent A. DiScala \\ From the Renal Service, Department of Medicine, U. S. Public Health Service \\ Hospital, Staten Island, New York 10304 and the Renal Division, \\ Department of Medicine, The Mount Sinai School of Medicine, \\ New York 10029
}

A в S T R A C T The exaggerated natriuresis of hypothyroid rats receiving a $5 \%$ saline infusion was studied to determine the mechanism and the site within the nephron responsible for this increase in sodium excretion. Sodium clearance $\left(\mathrm{C}_{\mathrm{Na}}\right)$ and fractional sodium excretion were both demonstrated to be greater in hypothyroid rats for any amount of sodium infused. The rate of increase in fractional sodium excretion in response to saline loading was 3.4 times greater in hypothyroid animals. At the conclusion of the diuresis some of the hypothyroid animals excreted greater than $45 \%$ of the filtered sodium load, while no control animal excreted more than $12 \%$ of the filtered sodium load.

The mean clearance of insulin during the saline diuresis was $36.6 \%$ lower $(P<0.001)$ in the hypothyroid rats. D-Aldosterone given to hypothyroid animals $3 \mathrm{hr}$ before the experiment did not alter the magnitude or rate of increase in fractional sodium excretion. Inulin space determinations in nephrectomized rats revealed that extracellular fluid volume was contracted by $17.1 \%$ in the hypothyroid rats $(P<0.01)$. Plasma sodium was not significantly different in hypothyroid and control animals.

A limit on solute free water reabsorption $\left(T^{c_{\mathbf{H}_{2}} \mathrm{O}}\right)$ per osmolar clearance (Cosm) was demonstrated in the hypothyroid rats when these animals excreted greater than $12 \%$ of the filtered osmotic load. The limit on $\mathrm{T}^{\mathrm{c}} \mathrm{H}_{2} \mathrm{O}$ formation was associated with an acceleration in the rate of sodium excretion and a decline in the rate of potassium excretion. Early in the diuresis when $\mathrm{Cosm}_{\mathrm{m}} \mathrm{C}_{\mathrm{Na}}$, and $\mathrm{T}_{\mathrm{H}_{2} \mathrm{O}}^{\mathrm{c}}$ were comparable in hypothyroid and control

An abstract of this work was published in 1969 in Abstracts of the Third Annual Meeting of The American Society of Nephrology.

Dr. Holmes is a Postdoctoral Research Fellow, U. S. Public Health Service, Health Services and Mental Health Administration, Federal Health Programs Service.

Received for publication 5 January 1970. rats, the filtered sodium load was $31 \%$ lower $(P<0.01)$ in the hypothyroid animals.

These findings indicate that diminished thyroid hormone activity decreases renal sodium reabsorptive capacity. Indirect evidence suggests that the distal and possibly the proximal tubules are the sites of this diminished sodium reabsorption in hypothyroid animals.

\section{INTRODUCTION}

Hypothyroidism has profound effects on salt and water metabolism in the rat. These are manifested by an increase in water consumption and excretion (1), inability to elaborate a maximally concentrated urine (2), exaggerated natriuresis during a water or saline diuresis $(3,4)$, and impaired ability to conserve sodium, resulting in a negative sodium balance and death when sodium intake is restricted (5). Fregly, Cade, Waters, Straw, and Taylor $(4,6)$ have demonstrated a decreased secretory rate and tubular response to aldosterone in hypothyroid rats, and they have proposed that thyroid insufficiency influences sodium reabsorption through this indirect mechanism. Reville and Stephan (7), however, have recently presented evidence in adrenalectomized hypothyroid rats which suggested that the alteration of sodium metabolism observed in hypothyroid animals was independent of adrenal function. In the present study several of the factors which regulate sodium reabsorption were evaluated with the hope of determining what mechanism might be responsible for this natriuresis. Also an attempt was made to localize the site(s) within the nephron responsible for this decrease in sodium reabsorption.

\section{METHODS}

Female, Wistar rats fed on a standard diet (Lab Blox, A1lied Mills, Inc., Chicago) ad libitum were employed for all 
studies. Control and hypothyroid rats were matched for age, and consequently, the slower growing hypothyroid rats had a lower mean weight than controls (234 g vs. $288 \mathrm{~g}$, respectively), although there was considerable overlap in the weight ranges.

Hypothyroid rats. Hypothyroidism was produced in the following manner: rats weighing approximately $200 \mathrm{~g}$ were maintained on a Remington "low iodine" diet (Nutritional Biochemicals Corp., Cleveland, Ohio) for 10 days, and then injected intraperitoneally with $1 \mathrm{mCi}$ of carrier-free Sodium Radio Iodide I-131 (E. R. Squibb and Sons, New York). The following day these rats were returned to the standard diet for the duration of the experiment. Rats were judged to be hypothyroid by the three following criteria: (a) failure of these animals, as pointed out above, to gain weight as rapidly as controls, $(b)$ inability to identify thyroid tissue at autopsy in the hypothyroid group of rats, and $(c)$ a significant drop in triiodothyronine $\left(\mathrm{T}_{3}\right)$ uptake by resinsponge $7 \mathrm{wk}$ after ${ }^{131} \mathrm{I}$ administration. $\mathrm{T}_{3}$ uptakes were performed with Triosorb-131 kits (Abbott) ${ }^{1}$ before and after ${ }^{131}$ I treatment in 12 rats. Blood for these determinations was obtained from the partially amputated tail in rats anesthetized with sodium pentobarbitol. Results are presented in Table I. The decline in $\mathrm{T}_{3}$ uptake after ${ }^{131} \mathrm{I}$ administration was highly significant $(P<0.001) . \mathrm{T}_{3}$ uptake has previously been demonstrated to be a reliable index of thyroid function in hypothyroid rats (8). The results of clearance studies in a second group of hypothyroid rats, who did not have blood drawn for $T_{3}$ uptake determinations, were indistinguishable from the results obtained in the first group with these determinations. Radio iodide used in this manner has been shown to produce the same renal ultrastructural changes as seen in hypothyroidism induced with propylthiouracil (9), and does not permanently alter parathyroid structure (10). Neither hypothyroidism nor radio iodide altered plasma urea (Table III). Neither the degree (as judged from depressions of $T_{3}$ uptake) nor the duration (6-16 wk after ${ }^{181}$ I administration) of hypothyroidism altered the results of clearance studies; therefore, results from all hypothyroid animals are reported together.

Clearance studies. The clearance studies were performed using the method of Buckalew, Ramirez, and Goldberg (11). After $24 \mathrm{hr}$ of dehydration with free access to food, anesthesia was induced with sodium pentobarbital $(5 \mathrm{mg}$ and $3.5 \mathrm{mg} / 100 \mathrm{~g}$ of body weight in controls and hypothyroids, respectively, due to the decreased tolerance of anesthesia by hypothyroid animals). Through a small suprapubic incision a No. 60 polyethylene catheter was inserted and secured into the bladder. Urine was collected in syringes graduated to the nearest $0.01 \mathrm{ml}$, and direct visualization assured complete bladder emptying by gentle pressure. Since micturition was induced before anesthesia, residual urine at the time of catheterization represented maximally concentrated urine $\left(U_{\max }\right)$. A tracheostomy was performed, and a No. 50 polyethylene catheter was inserted into the external jugular vein for the administration of priming and sustaining infusions. Sufficient inulin was given to attain blood levels of approximataely $100 \mathrm{mg} / 100 \mathrm{ml}$, and Pitressin was delivered at $0.01 \mathrm{U} / \mathrm{hr}$ per $100 \mathrm{~g}$ of body weight. These substances were infused at a constant rate of $0.0209 \mathrm{ml} / \mathrm{min}$ throughout the study. After a $1 \mathrm{hr}$ equilibration period, a $5 \%$ saline infusion was begun at rates varying from 0.110 to $0.250 \mathrm{ml} / \mathrm{min}$, and urine was collected every $5-10 \mathrm{~min}$

${ }^{1}$ We are indebted to Dr. Jonathan Miller of Abbott Laboratories, North Chicago, Ill., who kindly supplied a number of these Triosorb Kits.
TABLE 1

$T_{3}$ Resin Uptake before and after ${ }^{131}$ I Treatmen:

\begin{tabular}{cccc}
\hline $\begin{array}{c}\text { Rat } \\
\text { No. }\end{array}$ & $\begin{array}{c}\text { T3 uptake } \\
\text { before }{ }^{131} \text { I }\end{array}$ & $\begin{array}{c}\text { Ts uptake } \\
\text { 7 wa aft } \\
\text { 131 }\end{array}$ & Change \\
\hline 41 & $0.45^{*}$ & 0.36 & -0.09 \\
43 & 0.43 & 0.34 & -0.09 \\
45 & 0.47 & 0.39 & -0.08 \\
46 & 0.49 & 0.42 & -0.07 \\
51 & 0.49 & 0.42 & -0.07 \\
56 & 0.46 & 0.45 & -0.01 \\
58 & 0.50 & 0.34 & -0.16 \\
60 & 0.46 & 0.40 & -0.06 \\
64 & 0.52 & 0.36 & -0.16 \\
65 & 0.50 & 0.42 & -0.08 \\
66 & 0.50 & 0.40 & -0.10 \\
68 & 0.46 & 0.44 & -0.02 \\
& & & Mean $-0.0825 \pm 0.0130 \ddagger$ \\
& & & $(P<0.001)$ \\
\end{tabular}

* Ratio of $\mathrm{T}_{3}$ uptake by resin sponge to the total $\mathrm{T}_{3}$ added at the initiation of the incubation.

$\ddagger$ SEM.

after a sufficient diuresis was established. $1.5 \mathrm{ml}$ of blood were withdrawn in a heparinized syringe from the femoral vein during the first clearance period after the saline infusion was begun, and directly from the heart at the conclusion of the experiment. Since the rate of infusion did not vary during the course of individual experiments, plasma values for intermediate clearance periods were calculated by straight line interpolation between the initial and final samples. Preliminary studies in which blood was drawn during intermediate periods confirmed the reliability of this method.

Aldosterone studies. $3 \mathrm{hr}$ before initiation of the saline infusion, three hypothyroid rats were injected subcutaneously with $50 \mu \mathrm{g} / 100 \mathrm{~g}$ of body weight of $\mathrm{D}$-aldosterone in $38 \%$ ethanol (Ciba Pharmaceutical Co., Summit, N. J.), and a fourth rat received an additional infusion of $25 \mu \mathrm{g} / 100 \mathrm{~g}$ per $\mathrm{hr}$ intravenously throughout the study. Results of the clearance studies in all four rats were similar and are reported together.

Inulin space. Inulin space was determined by the method of White and Rolf (12) in five control and four hypothyroid rats. After dehydration and anesthetization as above, a bilateral nephrectomy was performed through a flank incision. Approximately $0.2 \mathrm{ml}$ of insulin solution was injected via the femoral vein, and the volume infused was determined to the nearest $0.001 \mathrm{ml}$ by weight. After exactly $1 \mathrm{hr}$ of equilibration a blood sample was withdrawn from the heart. Inulin space was calculated by the following formula:

$\frac{\begin{array}{c}\text { volume of inulin } \\ \text { injected }(\mathrm{ml})\end{array} \times \begin{array}{c}\text { inulin concentration of } \\ \text { this solution }(\mathrm{mg} / \mathrm{cc})\end{array}}{\text { plasma concentration of inulin }(\mathrm{mg} / \mathrm{cc})}$

and the result is expressed in $\mathrm{ml} / 100 \mathrm{~g}$ of body weight.

Analytical procedures and calculations. Osmolality was determined on a Fiske G-62 osmometer (Fiske Associates, Inc., Uxbridge, Mass.), sodium and potassium on an IL-143 flame photometer with internal lithium standard, and inulin (13) and urea (14) on a Technicon auto analyzer. 




FIGURE 1 Sodium clearance in nine hypothyroid and seven control rats. The mean $\mathrm{C}_{\mathrm{Na}} \pm_{\mathrm{SEM}}$ for each increment of $500 \mu \mathrm{Eq}$ of infused sodium is plotted against the mean cumulative sodium infused $\pm \mathrm{SEM}$ for this same increment. * indicates those means of the $\mathrm{C}_{\mathrm{Na}}$ which are significantly different $(P<0.05$ or less $)$ when hypothyroid and control values are compared.

All urine flow rates (V) are expressed in microliters per minute per $100 \mathrm{~g}$ of body weight. Previously it has been demonstrated that renal mass $/ 100 \mathrm{~g}$ of body weight is decreased in the hypothyroid compared to the control rat (4), and consequently the quantity of functional renal tissue is overestimated, if any thing, in the hypothyroid rat when the clearance data is adjusted to $100 \mathrm{~g}$ of body weight. The clearance of sodium $\left(\mathrm{C}_{\mathrm{Na}}\right)$, clearance of inulin $\left(\mathrm{C}_{\mathrm{in}}\right)$, osmolar clearance (Cosm), and solute free water reabsorption $\left(\mathrm{T}^{\mathrm{c}} \mathrm{H}_{2 \mathrm{O}}\right.$ ) were calculated by the standard formulas (15). Cumulative sodium infused at any point during the course of the diuresis represents the product of the sodium concentration of the infusate $x$ infusion rate $\times$ duration of the infusion, and is expressed as the microequivalents of sodium infused per $100 \mathrm{~g}$ of body weight. Group means and paired data were analyzed statistically by the Student's $t$ 


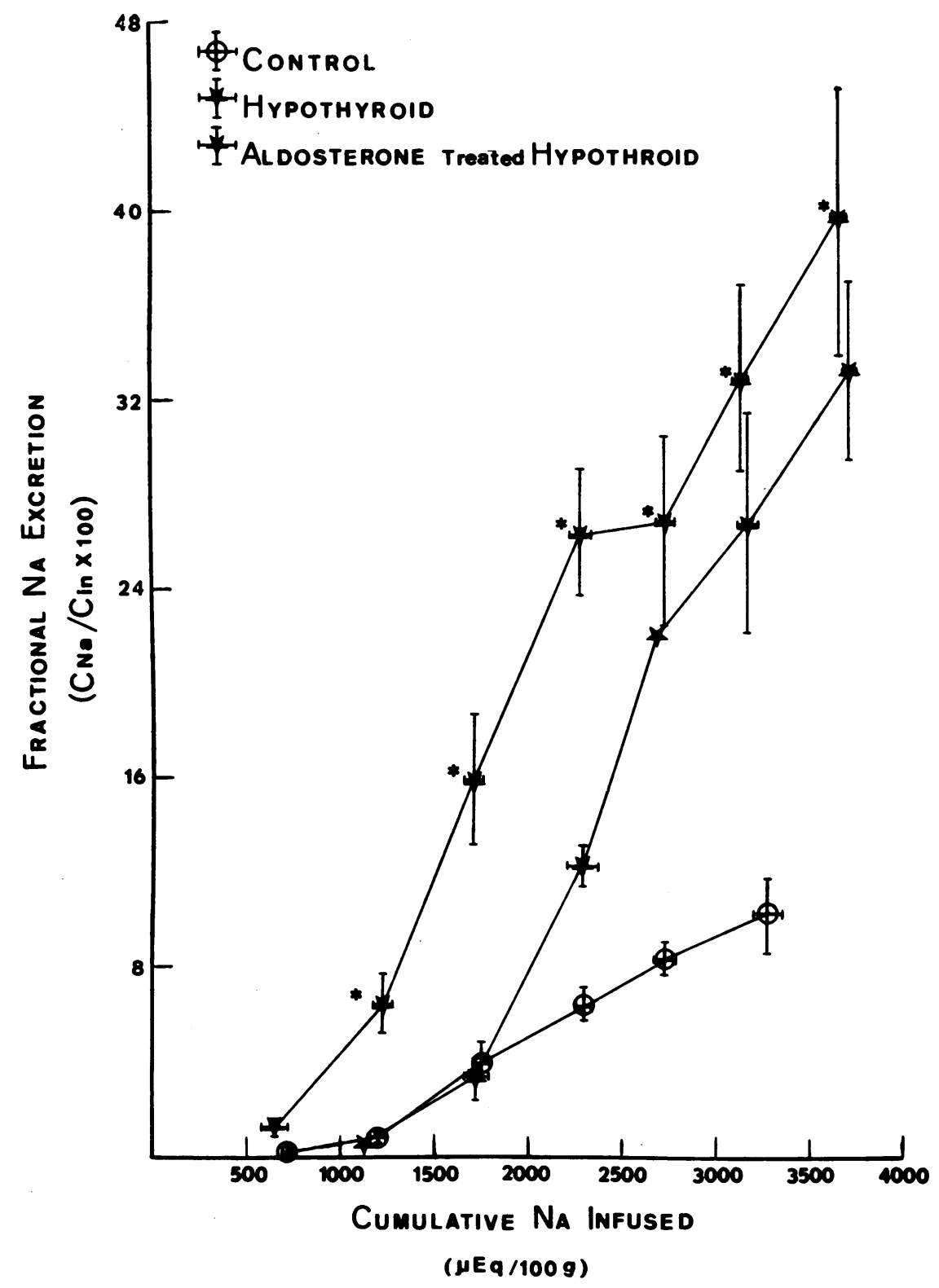

FIgURE 2 Fractional sodium excretion in nine hypothyroid and seven control rats. The mean fractional sodium excretion \pm SEM for each increment of $500 \mu \mathrm{Eq}$ of infused sodium is plotted against the mean cumulative sodium infused ISEM for this same increment. The three curves represent three different groups of rats: untreated control, untreated hypothyroid, and aldosterone-treated hypothyroid. * indicates those means of the fractional sodium excretion which are significantly different $(P<0.02$ or less) when untreated hypothyroid and control values are compared.

test and the means reported \pm 1 SEM (16). The regression equations and the error mean squares (EMS) were computed in the Biostatistics Branch of the Federal Health Programs Service (17). ${ }^{2}$

${ }^{2} \mathrm{We}$ are indebted to $\mathrm{Mr}$. Louis Bromer and Mr. David Evans for their assistance in this endeavor.

\section{RESULTS}

Sodium excretion. Comparisons of the $\mathrm{C}_{\mathrm{Na}}$ and the fractional excretion of sodium in seven control and nine hypothyroid rats are shown in Fig. 1 and Fig. 2. The data are presented as the mean $\mathrm{C}_{\mathrm{Na}}$ or the mean frac- 
TABLE II

Inulin Clearance and Inulin Space in Hypothyroid and Control Rats

\begin{tabular}{lcc}
\hline & \multicolumn{1}{c}{$\mathrm{C}_{\text {in }} *$} & Inulin space \\
\hline & $\mu 1 / \min$ & $m l / 100 \mathrm{~g}$ \\
per $100 \mathrm{~g}$ & \\
Hypothyroid & $628 \pm 28 \ddagger$ & $12.01 \pm 0.32$ \\
& $(\mathrm{n}=9)$ & $(\mathrm{n}=4)$ \\
Control & $990 \pm 51$ & $14.50 \pm 0.31$ \\
& $(\mathrm{n}=7)$ & $(\mathrm{n}=5)$ \\
$P$ value & $<0.001$ & $<0.01$ \\
\hline
\end{tabular}

$\mathrm{n}=$ number of animals studied.

* The $C_{i n}$ represents the mean of the mean of all clearance periods after the saline infusion was begun.

$\ddagger$ SEM.

tional sodium excretion \pm SEM during each successive increment of $500 \mu \mathrm{Eq}$ of sodium infused per $100 \mathrm{~g}$ of body weight. The cumulative sodium infused during each of these increments is also presented as the mean ISEM. Fig. 1 demonstrates that the mean $\mathrm{C}_{\mathrm{Na}}$ was greater in the hypothyroid rats for any given amount of sodum infused; however, the difference in the $\mathrm{C}_{\mathrm{Na}}$ did not become statistically significant until more than $1500 \mu \mathrm{Eq}$ of sodium had been infused. This point in the diuresis $(1500$ $\mu \mathrm{Eq}$ of sodium infused) corresponded to a mean Cosm of $95 \mu 1 / \mathrm{min}$ per $100 \mathrm{~g}$ in the hypothyroid rats.

The $C_{\text {in }}$ was measured simultaneously with sodium excretion in the above rats, and these results are presented in Table II. The mean $\mathrm{C}_{\text {in }}$ during the saline diuresis was $36.6 \%$ lower in the hypothyroid rats $(P<$ $0.001)$. During the course of the saline diuresis, the $C_{i n}$ was relatively constant or tended to decrease slightly in individual experiments; in no case was there a significant increase in the $C_{\text {in }}$ after the diuresis was initiated.

Fractional sodium excretion was also found to be greater in the hypothyroid rat for any given amount of sodium infused. At the conclusion of the diuresis three of the nine hypothyroid animals excreted more than $45 \%$ of the filtered sodium load, while no control animal excreted more than $12 \%$ of the filtered sodium load. Because the filtered sodium load was lower in the hypothyroid animals, the difference in fractional sodium excretion between hypothyroid and control rats was greater than the difference in $\mathrm{C}_{\mathrm{Na}}$ (comparison of Fig. 1 and Fig. 2). For this reason, statistically significant differences in fractional sodium excretion occur earlier in the course of the diuresis than significant differences in $\mathrm{C}_{\mathrm{Na}}$, and this could explain the failure of some studies (18) to demonstrate a significant difference in sodium excretion between hypothyroid and control rats when $\mathrm{U}_{\mathrm{Na}} \mathrm{V}$ alone is compared in these animals.
The natriuretic response of the hypothyroid rat differs, not only in the amount, but also the rate at which sodium is cleared or excreted. Fig. 1 and Fig. 2 both suggest that the slopes of the $\mathrm{C}_{\mathrm{Na}}$ and fractional sodium excretion curves are greater in the hypothyroid rat. A more precise analysis is possible by comparing the equations obtained when the regression of fractional sodium excretion on cumulative sodium infused is calculated. The second order regression equations (line of best fit) for controls and hypothyroids are $\hat{y}=-4.91$ $+0.0063 x-0.00000058 x^{2}$ with EMS $=4.48$ and $\hat{y}=-$ $15.007+0.022 x-0.0000022 x^{2}$ with EMS $=73.52$, respectively $(P<0.01)$. The slope of the fractional sodium excretion curve is approximately 3.4 times greater in the hypothyroid than control group of rats within the diuretic range of the present studies. Since the slope of the curve is the rate of increase in fractional sodium excretion, it follows that fractional sodium excretion was increasing about 3 times more rap:dly in the hypothyroid animals in response to a saline infusion. Although five of the nine hypothyroid rats were infused with $5 \%$ saline at a more rapid rate than controls to compensate for the increased rate of sodium excretion, four of the nine hypothyroid an:mals had 5\% saline infused at the same rate as control rats. Since the more rapid increase in fractional sodium excretion was observed in both of these groups of hypothyroid rats, the rate at which saline was infused does not explain the differences in the rate of sodium excretion between hypothyroid and control animals.

During the course of these studies, it was observed that the hypothyroid rats had a greater tolerance to the hypertonic saline infusion. Tolerance is defined here as the amount of cumulative sodium infused before the animal deteriorated. Six of nine hypothyroid, compared to two of seven control rats, tolerated an infusion of greater than $3000 \mu \mathrm{Eq}$ of $\mathrm{Na}$ per $100 \mathrm{~g}$ before $\mathrm{V}, \mathrm{C}_{\mathrm{Na}}$, and $\mathrm{C}_{\text {in }}$ began to fall abruptly. This incidental observation provides further evidence of the difference in the response of hypothyroid and control rats to a salt infusion.

Aldosterone response. Also presented in Fig. 2 is the fractional sodium excretion data for four additional hypothyroid rats treated with 50 times the dose of D-aldosterone previously found to be effective in reducing sodium excretion in hypothyroid rats (4). Inspection of the curve reveals that it is very similar in contour to that observed in untreated hypothyroid rats, but it is displaced to the right. The regression equations of fractional sodium excretion on cumulative sodium infused for the aldosterone-treated and untreated hypothyroid rats $\left(\hat{y}=-29.43+0.024 x-0.0000022 x^{2}\right.$, $\mathrm{EMS}=37.58 ; \hat{y}=-15.007+0.022 x-0.0000022 x^{2}$, $\mathrm{EMS}=73.52$, respectively) are not significantly different from each other, but both are significantly different 
TABLE III

Base Line Plasma and Urine Determinations in Hypothyroid and Control Rats

\begin{tabular}{|c|c|c|c|c|c|c|}
\hline & $\mathrm{P}_{\mathrm{Na}} *$ & $\mathbf{P K}^{*}$ & Purea* & Uosmt & Uurest & $\begin{array}{l}\text { U nonurea† } \\
\text { solute }\end{array}$ \\
\hline & $m E q /$ liter & $m E q /$ liter & $m g / 100 \mathrm{ml}$ & $\mathrm{mOsm} / \mathrm{kg}$ & $m M /$ liter & $m M /$ liter \\
\hline Hypothyroid & $\begin{array}{c}144 \pm 2.3 \S \\
(\mathrm{n}=9)\end{array}$ & $\begin{array}{c}3.27 \pm 0.15 \\
(\mathrm{n}=9)\end{array}$ & $\begin{array}{l}33 \pm 2.1 \\
(\mathrm{n}=9)\end{array}$ & $\begin{array}{c}2109 \pm 144 \\
(\mathrm{n}=9)\end{array}$ & $\begin{array}{c}1182 \pm 148 \\
(n=9)\end{array}$ & $\begin{array}{c}927 \pm 76 \\
(\mathrm{n}=9)\end{array}$ \\
\hline Control & $\begin{array}{c}148 \pm 2.2 \\
(\mathrm{n}=7)\end{array}$ & $\begin{array}{c}3.67 \pm 0.10 \\
(\mathrm{n}=7)\end{array}$ & $\begin{array}{c}30 \pm 2.9 \\
(\mathrm{n}=7)\end{array}$ & $\begin{array}{c}3172 \pm 109 \\
(\mathrm{n}=5)\end{array}$ & $\begin{array}{c}2163 \pm 105 \\
(n=5)\end{array}$ & $\begin{array}{c}1009 \pm 113 \\
(\mathrm{n}=5)\end{array}$ \\
\hline$P$ value & $>0.40$ & $>0.10$ & $>0.60$ & $<0.01$ & $<0.01$ & $>0.60$ \\
\hline
\end{tabular}

$\mathrm{n}=$ number of animals studied.

* Plasma concentration just before starting saline infusion.

¥ Urine concentration after $24 \mathrm{hr}$ dehydration.

$\S$ SEM.

$(P<0.01)$ from the equation calculated for the untreated control rats $(\hat{y}=-4.91+0.0063 x-0.000$ $\left.00058 x^{2}, \mathrm{EMS}=4.48\right)$. A comparison of the regression equations for the aldosterone-treated and untreated hypothyroid rats confirms that the slopes of the fractional excretion curves are practically identical and that the curve for the aldosterone-treated hypothyroid rats is shifted to the right. Likewise, the maximum values for fractional sodium excretion at the end of the diuresis were not significantly different in untreated and aldosterone-treated hypothyroid animals, with some animals in both groups excreting as much as $45 \%$ of the filtered load of sodium.

Extracellular volume. Inulin space has previously been demonstrated to be a reliable measure of extracellular volume in the nephrectomized rat (12) and was

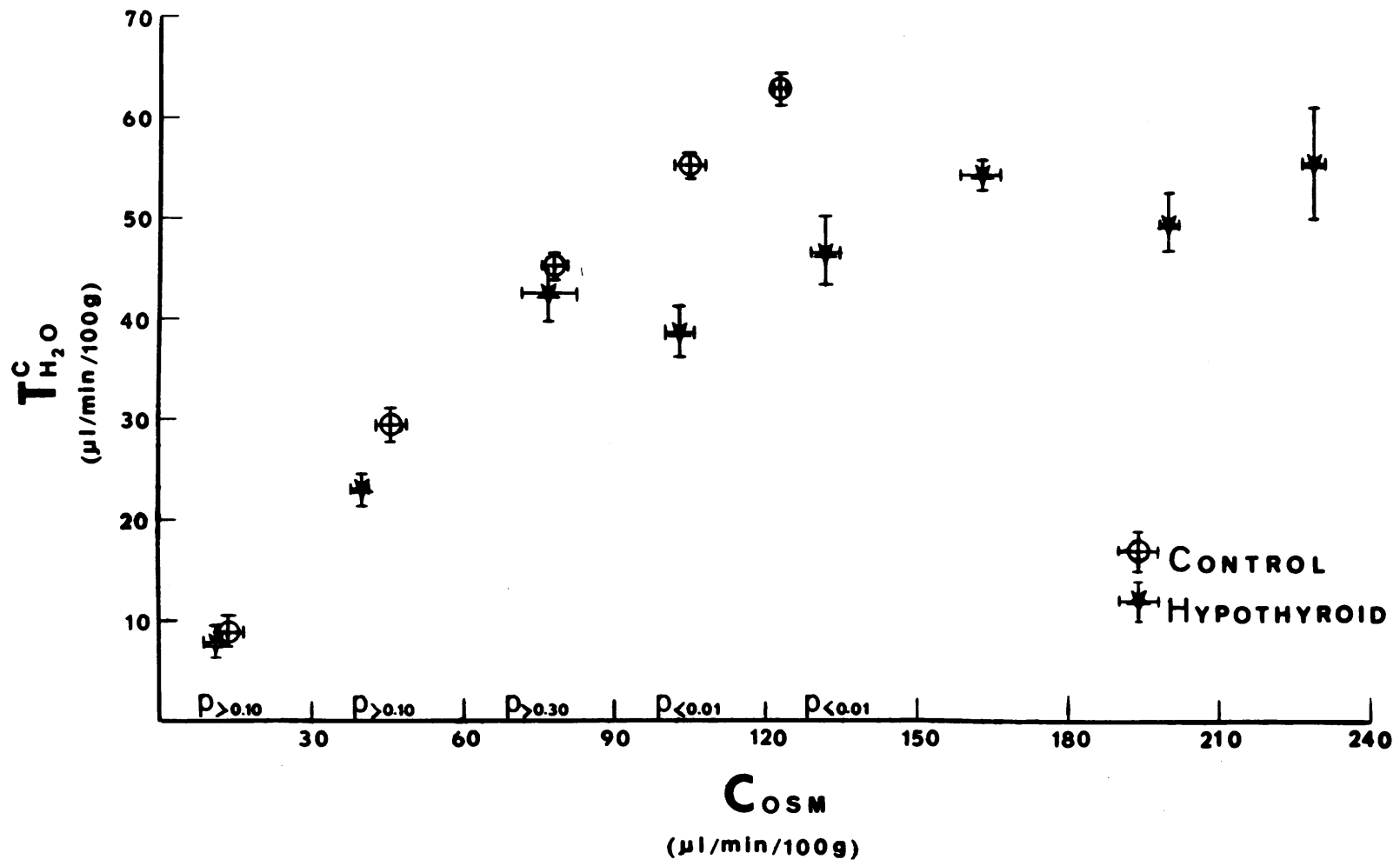

FIGURE 3 Solute free water reabsorption in hypothyroid and control rats. The means $\pm_{\text {SEM }}$ for $\mathrm{T}^{\mathrm{c}}{ }_{\mathrm{H} 2 \mathrm{O}}$ and $\mathrm{C}_{\mathrm{Osm}}$ were computed for both groups for each $\mathrm{C}_{\mathrm{osm}}$ increment of $30 \mu \mathrm{l}$. The mean $\mathrm{T}_{\mathrm{H}_{2} \mathrm{O}}$ per $\mathrm{C}_{\mathrm{osm}}$ was compared in hypothyroid and control rats in each increment of $\mathrm{C}_{0 \mathrm{sm}}$ and the $P$ value is recorded on the abscissa. 


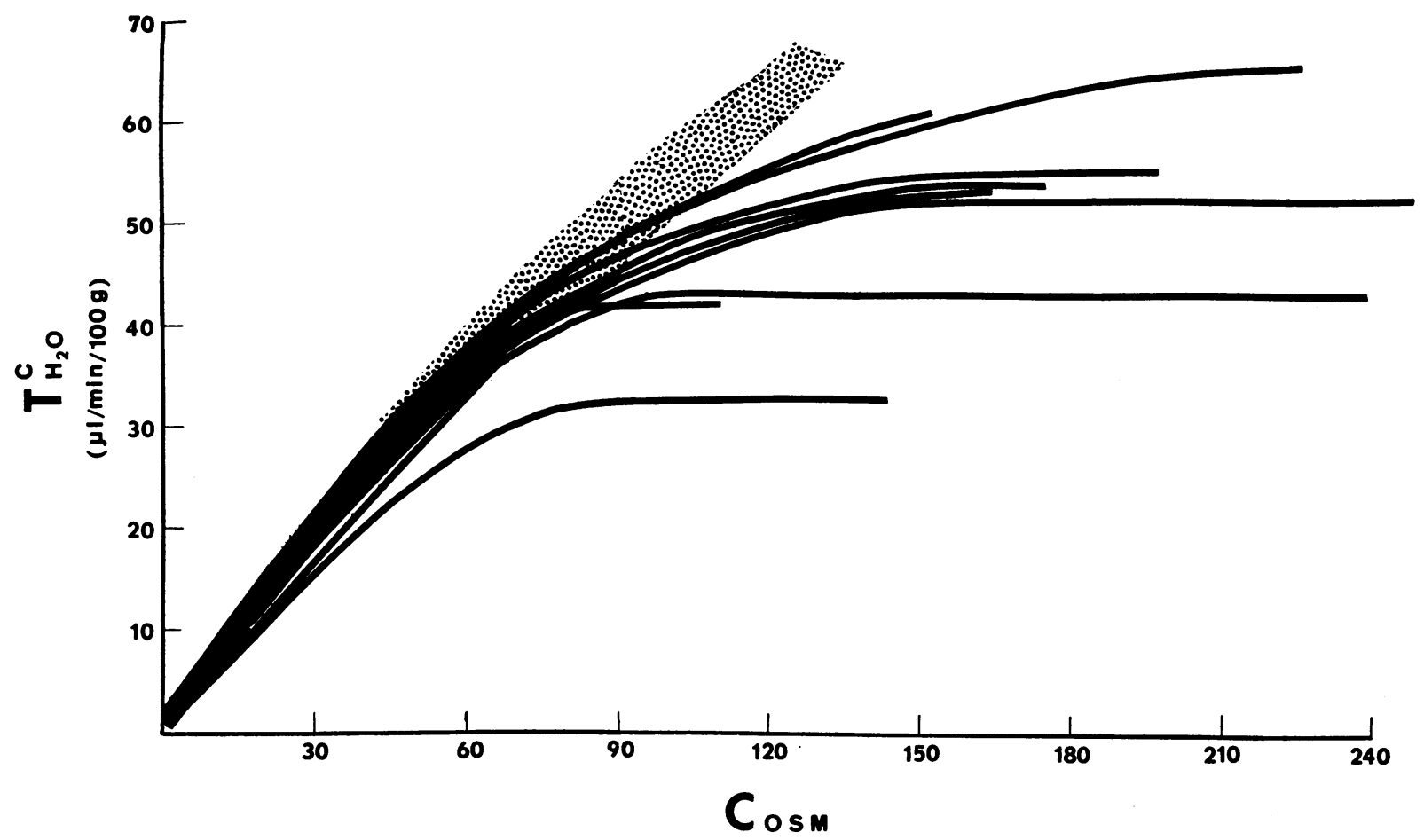

$(\boldsymbol{\mu} / / \mathrm{min} / 100 \mathrm{~g})$

Figure 4 Individual $\mathrm{T}^{\mathrm{c}}{ }_{\mathrm{H}_{2} \mathrm{O}}$ per $\mathrm{C}_{\mathrm{O} \mathrm{sm}}$ curves for hypothyroid rats. The shaded area is a composite of the $\mathrm{T}^{\mathbf{c}}{ }_{\mathrm{H} 2 \mathrm{O}}$ per $\mathrm{C}_{\mathrm{osm}}$ curves for control rats.

used for that purpose in these studies. The results are presented in Table II. The mean inulin space as determined in five control rats was $14.50 \mathrm{ml} / 100 \mathrm{~g}$ of body weight, while the mean inulin space in four hypothyroid rats was $12.01 \mathrm{ml} / 100 \mathrm{~g}$ of body weight $(P<0.01)$. This represents an extracellular volume contraction of $17.1 \%$ in the hypothyroid rat.

Plasma sodium and potassium. The mean plasma sodium $\left(\mathrm{P}_{\mathrm{Na}}\right)$ and plasma potassium $\left(\mathrm{P}_{\mathrm{K}}\right)$ for control and hypothyroid rats at the initiation of the saline diuresis are presented in Table III. $P_{\mathrm{Na}}$ and $P_{\mathrm{K}}$ were not significantly different between the two groups $(P>0.40$ and $P>0.10$, respectively).

Solute free water reabsorption. In Fig. $3 \mathrm{~T}^{\mathrm{c}} \mathrm{H}_{2} \mathrm{O} / 100$ $\mathrm{g}$ of body weight is plotted against $\mathrm{Cosm}_{\mathrm{m}} / 100 \mathrm{~g}$ of body weight for the same control and hypothyroid rats described above. Below a Cosm of $90 \mu 1 / \mathrm{min}$ per $100 \mathrm{~g}$, or over approximately the first third of the diuretic range observed in hypothyroid animals, there was no statistical difference in $\mathrm{T}^{\mathbf{c}}{ }_{\mathrm{H}_{2} \mathrm{O}}$ formation in hypothyroid and control rats. However, as Cosm continued to increase from 90 to $150 \mu 1 / \mathrm{min}$ per $100 \mathrm{~g}, \mathrm{~T}_{\mathrm{H}_{2} \mathrm{O}}^{\mathrm{c}}$ failed to increase as rapidly in hypothyroid as control rats. The lower $T^{\mathbf{c}}{ }_{\mathrm{H}_{2} \mathrm{O}}$ values found in hypothyroid animals over this Cosm range were significantly different. It should be recalled that at approximately this same point in the diuresis, a mean $C_{0 s m}$ of $95 \mu 1 / \mathrm{min}$ per $100 \mathrm{~g}$, the $\mathrm{C}_{\mathrm{Na}}$ started to increase more rapidly and became significantly greater in the hypothyroid rats. As Cosm continued to increase in hypothyroid animals, $\mathrm{T}^{\mathbf{c}}{ }_{\mathrm{H}_{2} \mathrm{O}}$ formation remained relatively constant. Many of the individual hypothyroid rats reached an actual plateau in the $\mathrm{T}_{\mathrm{H}_{2} \mathrm{O}}^{\mathrm{c}} / \mathrm{Cosm}_{\mathrm{m}}$ curve, but this cannot be appreciated on a mass plot; therefore, a composit of curves from individual rats is presented in Fig. 4. Unfortunately, it was not possible to achieve a Cosm of greater than $130 \mu 1 / \mathrm{min}$ per $100 \mathrm{~g}^{3}$ in any control animal, and consequently the last half of the diuretic range achieved by the hypothyroid rats cannot be compared to controls. Since the present experimental protocol was designed after the method of Buckalew et al. (11), it is interesting to note that these investigators found $\mathrm{T}^{\mathrm{c}} \mathrm{H}_{2} \mathrm{O}$ formation to increase linearly in some controls up to a Cosm of $240 \mu 1 / \mathrm{min}$ per $100 \mathrm{~g}$.

Because of the lower GFR in the hypothyroid animals

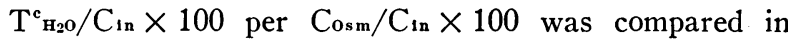

\footnotetext{
${ }^{3}$ Attempts to increase $\mathrm{C}_{\mathrm{osm}}$ in controls by increasing salt content of the diet, pretreatment with acetazolamide, and chronic aldosterone administration were uniformly unsuccessful. No explanation is available to explain the present failure to achieve $C_{0 s m}$ values as great as those previously reported for some control animals (11).
} 


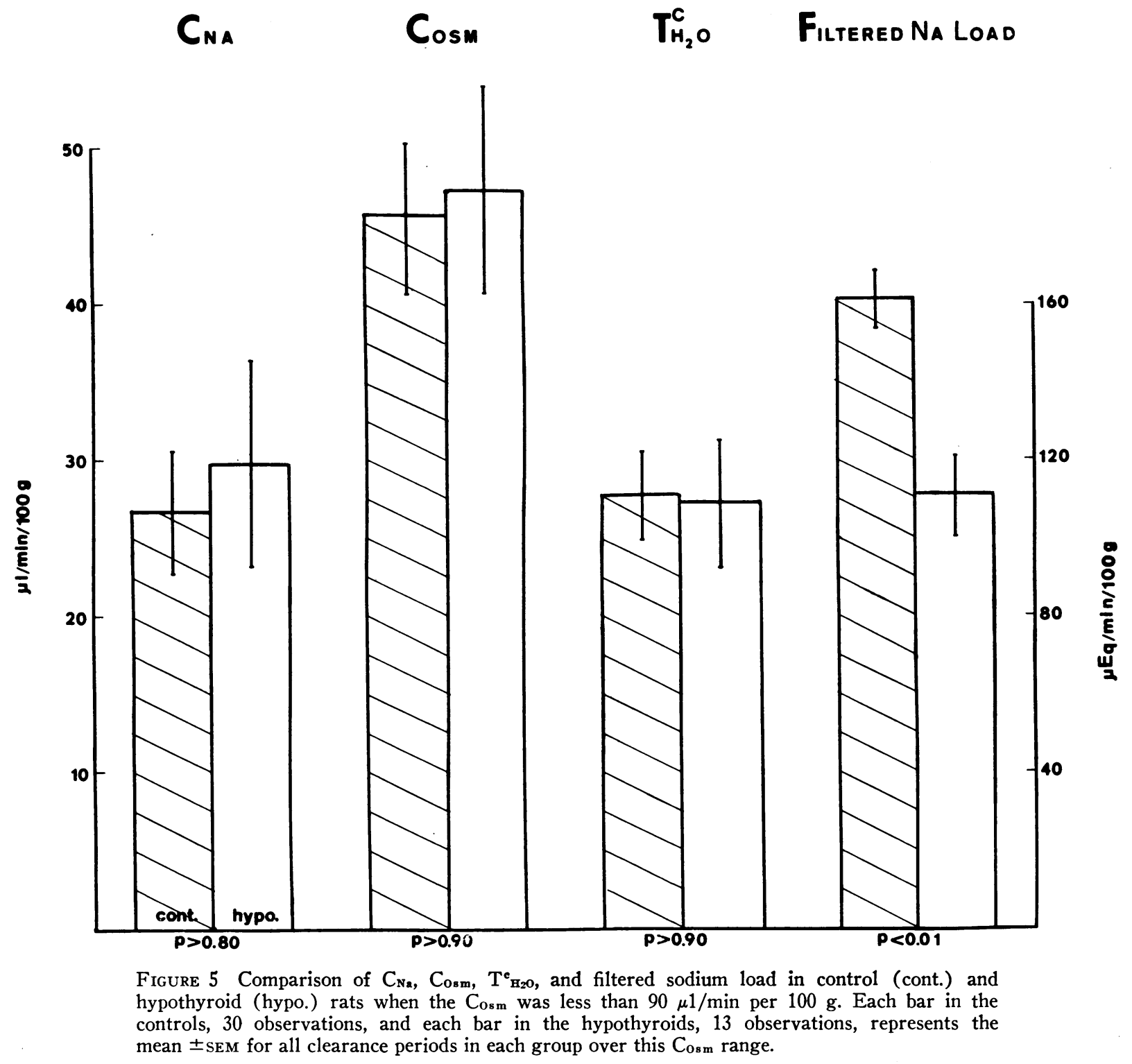

hypothyroid and control rats. Although the results are not presented graphically, it can be stated that the limit on fractional $\mathrm{T}^{\mathrm{e}} \mathrm{H}_{20}$ formation by hypothyroid rats in the last half of the diuresis was still demonstrable. No difference in fractional $T^{\mathbf{c}}{ }_{\mathrm{H}_{2} \mathrm{O}}$ formation between hypothyroid and control animals could be discerned in the first one third of the diuretic range obtained in hypothyroid rats.

In Fig. 5, the mean values for $\mathrm{C}_{\mathrm{Na}}, \mathrm{Cosm}_{\mathbf{m}}, \mathrm{T}^{\mathrm{c}} \mathrm{H}_{\mathbf{2}}$, and filtered sodium load for all clearance periods below a Cosm of $90 \mu 1 / \mathrm{min}$ per $100 \mathrm{~g}$ are compared in hypothyroid and control animals. It can be seen that the mean $\mathrm{C}_{\mathrm{Na}}$, Cosm, and $\mathrm{T}^{\mathrm{c}}{ }_{\mathrm{H} 2 \mathrm{O}}$ were not significantly different in these two groups of rats over approximately one third of the diuretic range observed in hypothyroid animals. However, while sodium and osmolar clearances, as well as solute free water reabsorption, were comparable in hypothyroid and control rats at this stage in the diuresis, filtered sodium load was on the average $31 \%$ lower $(P<0.01)$ in the hypothyroid animals.

Potassium excretion. In Fig. 6 potassium excretion $\left(\mathrm{U}_{\mathrm{K}} \mathrm{V}\right)$ per $100 \mathrm{~g}$ of body weight is plotted against sodium excretion $\left(\mathrm{U}_{\mathrm{Na}} \mathrm{V}\right)$ per $100 \mathrm{~g}$ of body weight. Early in the diuresis $U_{\mathrm{kV}} \mathrm{V}$ increased rapidly in both groups of animals. $U_{K} V$ reached a maximum and then seemed to decline in hypothyroid rats, while it continued to increase in controls over the entire range of the diuresis. This difference in $\mathrm{U}_{\mathrm{K}} \mathrm{V}$ did not become 


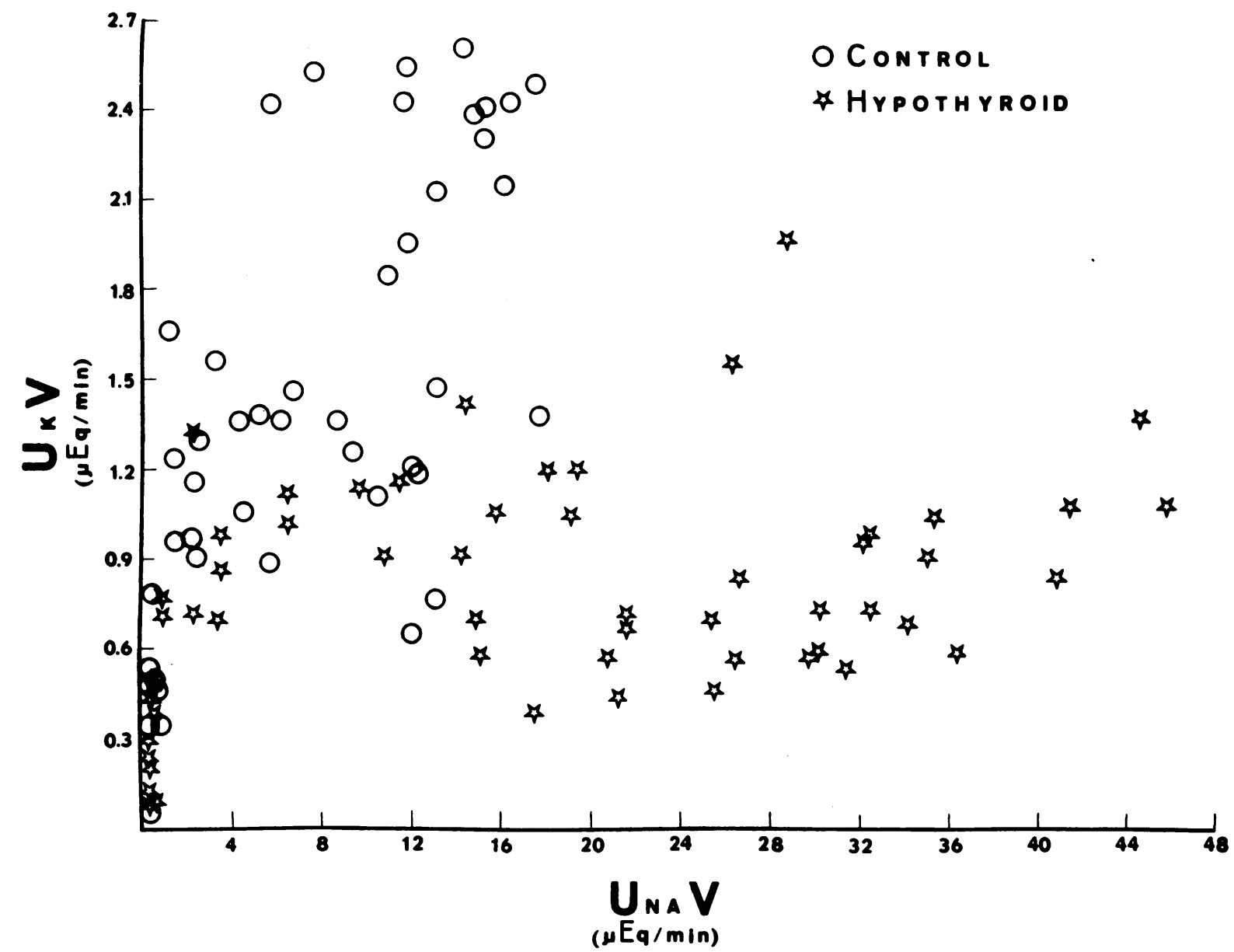

FIGURE 6 Potassium excretion in hypothyroid and control rats. $\mathrm{U}_{\mathrm{K}} \mathrm{V}$ is graphed as a function of sodium excretion $\left(\mathrm{U}_{\mathrm{Na}} \mathrm{V}\right)$.

marked until $\mathrm{U}_{\mathrm{Na}} \mathrm{V}$ was greater than $12 \mu \mathrm{Eq} / \mathrm{min}$ per $100 \mathrm{~g}$, which corresponded to a Cosm of approximately $90 \mu 1 / \mathrm{min}$ per $100 \mathrm{~g}$ in the hypothyroid rats.

Urine concentration. An analysis of maximally concentrated urine in hypothyroid and control rats is presented in Table III. The lower urine concentration was due almost entirely to a lower urea concentration, since nonurea solutes were not significantly different. In Fig. 7, $\mathrm{V}$ and $\mathrm{U}_{\text {urea }}$ are compared in hypothyroid and control rats during the equilibration period and throughout the diuresis. No difference in Uurea between these two groups of animals was apparent if $U_{u r e a}$ was related to V. Although not shown here, $\mathrm{Curea}_{\mathrm{C}} / \mathrm{C}_{\text {in }}$ vs. $\mathrm{V}$ was no different in control and hypothyroid rats.

\section{DISCUSSION}

The response of hypothyroid rats to a saline infusion was found to differ in several respects from that observed in controls. It was demonstrated that the kidney of the hypothyroid rat cleared more sodium both absolutely and fractionally for any given amount of sodium infused. A comparison of the regression equations for the fractional excretion of sod um in hypothyroid and control rats reveals that the rate of increase in fractional sodium excretion is approximately 3 times greater in the hypothyroid rat. These results indicate that the kidney of the hypothyroid rat is reabsorbing a smaller percentage of the filtered sodium load than the kidney of control rats at any time during the course of saline loading, and that some site(s) along the nephron is responding to the saline infusion by decreasing sodium reabsorption more rapidly in the hypothyroid animals.

Renal sodium reabsorption is known to be influenced by a number of factors, such as, glomerular filtration rate (GFR), aldosterone, extracellular fluid volume, plasma sodium concentration, and certain physical factors. The finding of an exaggerated natriuretic response to saline loading in the hypothyroid rat may be 




FigURE 7 Urinary urea concentration relative to urine flow rate. Values for $\mathrm{U}_{\mathrm{urea}}$ and $\mathrm{V}$ represent data obtained during the equilibration period and throughout the saline diuresis.

explained on the basis of one of these mechanisms or it may be the direct result of an insufficiency of thyroid hormone. Some reports in the literature suggest an indirect effect $(4,6)$, while others suggest a direct effect $(7,19)$, but none of these investigations explored systematically the mechanisms which are presently felt to control sodium reabsorption.

Since the $\mathrm{C}_{\mathrm{tn}} / 100 \mathrm{~g}$ of body weight was on the average $36.6 \%$ lower in the hypothyroid rats, the greater $\mathrm{C}_{\mathrm{N}_{\mathrm{a}}} /$ $100 \mathrm{~g}$ observed in these animals cannot be attributed to an increase in the $\mathrm{C}_{\mathrm{in}} / 100 \mathrm{~g}$. The only previous report of GFR in the hypothyroid rat (20) found similar reductions in the $\mathrm{C}_{\text {in }}$ per body weight, but these investigators correlated this finding with a smaller kidney mass per body weight in the hypothyroid rat. If in the present studies the $C_{i n}$ had been related to kidney rather than body weight, it is possible that the differences in the $C_{\text {in }}$ between hypothyroid and control rats may have been decreased; however, such a maneuver would have exaggerated the differences in the $\mathrm{C}_{\mathrm{Na}}$ and could not, therefore, account for the observed differences in $\mathrm{C}_{\mathrm{Na}}$. Also, the increased rate of sodium clearance observed in hypothyroid animals cannot be explained by GFR since the $\mathrm{C}_{1 n}$ did not increase during the course of the saline diuresis.

It has been observed that hypothyroid rats have a decreased secretory rate and a decreased tubular response to aldosterone $(4,6)$, and from these results it has been suggested that a lack of aldosterone action was responsible for the exaggerated natriuretic response. However, the magnitude of the fractional sodium excretion demonstrated in hypothyroid rats in the present study makes this explanation seem unlikely for the following two reasons. First, complete adrenalectomy in- 
creases fractional excretion by only $1-2 \%$ (21), while fractional sodium excretion was increased by $330 \%$ in the hypothyroid rats; second, totally adrenalectomized rats undergoing a saline-mannitol diuresis excrete only $9 \%$ of the filtered sodium load (22), while in the present studies on much as $45 \%$ of the filtered load was excreted by some of the hypothyroid rats. A comparison of the curves and regression equations of fractional sodium excretion in aldosterone-treated and untreated hypothyroid animals reveals that the more rapid rate of increase in fractional sodium excretion was not altered in hypothyroid rats by pretreatment with aldosterone. Likewise, the maximum values obtained for fractional sodium excretion at the conclusion of the diuresis were not significantly different in aldosterone-treated and untreated hypothyroid animals. However, the onset of the natriuresis in aldosterone-treated hypothyroid animals was delayed and this suggests that the aldosterone was effective. Because of this delay in onset, the curves for fractional sodium excretion in aldosterone-treated hypothyroid and untreated control rats partially overlapped. Since the regression equations for fractional sodium excretion in aldosterone-treated hypothyroid and untreated control rats are significantly different and a similar delay in the onset of the natriuresis may have been observed if control rats had been treated with such large doses of aldosterone, the physiologic significance of the overlap in fractional sodium excretion between these two groups of rats seems doubtful. Therefore, it appears that the characteristic renal response of hypothyroid rats to a saline infusion, a large and rapid increase in sodium excretion, is not altered by exogenous administration of effective doses of aldosterone. This indicates that the observed changes in secretory rate and tubular response to aldosterone are not the primary factors responsible for the hypothyroid animals' exaggerated natriuretic response to a saline infusion.

In addition to GFR and aldosterone, alterations in the extracellular fluid volume are recognized to be important determinants of sodium excretion. In rats undergoing a saline diuresis, sodium excretion was demonstrataed to vary directly with changes in extracellular volume (23). Under the present experimental conditions extracellular volume, as measured by inulin space, was demonstrated to be $17.1 \%$ lower in the hypothyroid animals. The finding of an inverse relationship between sodium excretion and extracellular volume in the hypothyroid rat does not explain the exaggerated natriuresis observed in these animals.

Plasma sodium concentration, independent of extracellular volume expansion, has also been shown to alter sodium excretion (24). Since $\mathrm{P}_{\mathrm{Na}}$ was not significantly different in control and hypothyroid rats, it is not likely that this is the explanation for the greater saluresis observed in hypothyroid animals.

Hemodynamic and physical factors can also influence salt excretion (25). Koehn, Schindler, and Stanton (26) demonstrataed that aortic perfusion pressure was reduced by approximately $17 \%$ in radiothyroidectomized rats; Reville and Stephan $(7,19)$ found an elevated plasma protein concentration in dehydrated hypothyroid rats; and Osorio and Zadunaisky (20) demonstrated that the clearance of Diodrast was decreased by $66 \%$ in conjunction with a $33 \%$ reduction in the $\mathrm{C}_{1 \mathrm{n}}$ and resulted in an increased filtration fraction in these animals. These reports in nondiuretic hypothyroid rats suggest that physical factors are not responsible for the exaggerated natriuretic response of these animals because the observed alterations in physical parameters are the reverse of those required to explain an increase in sodium excretion. Such a mechanism, however, cannot be definitely excluded until these parameters are measured in hypothyroid and control rats during a saline diuresis.

The explanation for the exaggerated natriuretic response of hypothyroid rats was not found in the present investigations into the mechanisms which control sodium reabsorption. On the contrary, the finding of increased sodium excretion in animals with a contracted extracellular volume suggests that some factor is operating in these animals to oppose a potent stimulus for sodium reabsorption. Because no other explanation is forthcoming, it is proposed that this factor responsible for the exaggerated natriuresis found in the hypothyroid animals is an insufficiency of thyroid hormone. This suggests that a certain minimal amount of thyroid hormone is necessary to maintain the maximum sodium reabsorptive capacity of the kidney. A direct effect of thyroxine on sodium transport has been demonstrated in the isolated toad bladder $(27,28)$, and the present studies are compatible with a direct effect of thyroid hormone on the renal tubule. However, the data do not exclude an indirect action through some unknown or as yet unexplored mechanism, such as a natriuretic hormone (29) or a redistribution of renal blood flow (30, 31).

The site(s) within the nephron responsible for the exaggerated natriuretic response of hypothyroid animals was examined through a comparison of $\mathrm{T}^{\mathrm{c}}{ }_{\mathrm{H}_{2} \mathrm{O}}$ in hypothyroid and control rats. $\mathrm{T}^{\mathbf{c}} \mathbf{H}_{2} \mathrm{O}$ formation increased linearly in control rats throughout the study, while the hypothyroid rats demonstrated an impaired ability to generate $\mathrm{T}^{\mathrm{c}}{ }_{\mathrm{H}_{2} \mathrm{O}}$ above a Cosm of $90 \mu 1 / \mathrm{min}$ per $100 \mathrm{~g}$. Concomitant with the failure for $T^{c}{ }_{\mathrm{H}_{2} \mathrm{O}}$ to rise the absolute and fractional $\mathrm{C}_{\mathrm{Na}}$ were increasing more rapidly in the hypothyroid rats. The only other report in the literature dealing with solute free water reabsorption in 
hypothyroid and control rats had a different experimental design and studied rats during a hypertonic mannitol diuresis. Still, the results indicated that $\mathrm{T}_{\text {ноО }}^{\mathrm{c}}$ formation was depressed in conjunction with an increase in sodium excretion in the hypothyroid rat (32). Although it cannot be excluded that an increase in medullary blood flow and/or a decrease in water permeability at the distal tubular sites were partly responsible for the limit on $\mathrm{T}^{\mathrm{c}}{ }_{\mathrm{H} 2 \mathrm{O}}$ formation, it seems probable that a decrease in sodium reabsorption in some portion of the distal nephron of hypothyroid animals is partly responsible for the limit on $\mathrm{T}^{\mathbf{c}}{ }_{\mathrm{H}_{2} \mathrm{O}}$ formation and the associated increase in the rate of sodium excretion. Likewise, the concomitant increase in the rate of sodium excretion and decrease in the rate of potassium excretion demonstrated in hypothyroid animals suggests that the distal convoluted tubule may be contributing to the natriuresis, since one of the factors known to regulate potassium secretion is the electrical gradient generated by sodium reabsorption in the distal convoluted tubule (33). Whether the entire distal nephron (the loop of Henle, convoluted tubule, and collecting duct) or only part of it is responsible for the natriuresis observed in hypothyroid animals cannot be determined by the present studies.

Because some of the hypothyroid rats excreted greater than $45 \%$ of the filtered sodium load, this suggested that the proximal tubule may also be contributing to the natriuresis (34). When $C_{o s m}, C_{\mathrm{Na}}$, and $\mathrm{T}^{\mathrm{H}_{2} \mathrm{O}}$ were compared over that range of the diuresis where $\mathrm{T}^{\mathrm{c}}{ }_{\mathrm{H} 2 \mathrm{O}}$ was increasing linearly in both hypothyroid and control rats, it was found that the mean $\mathrm{C}_{\mathrm{Na}}$ and $\mathrm{Cosm}_{\mathrm{s}}$ were not significantly different in these two groups, while the mean filtered sodium load was $31 \%$ lower in the hypothyroid animals. This indicates that fractional sodium reabsorption was decreased in some part of the nephron in the hypothyroid animals. Since sodium reabsorption in the distal nephron appears to be comparable in both groups of rats at this stage in the diuresis (comparison of $\mathrm{T}_{\mathrm{H}_{2} \mathrm{O}}^{\mathbf{c}_{\mathrm{O}}}$ per $\mathrm{Cosm}_{\mathrm{s}}$ ), this might imply that fractional sodium reabsorption in the proximal tubule was inhibited to a greater extent in the hypothyroid animals. Proof of this, however, must await more direct studies.

The inability of hypothyroid rats to elaborate a maximally concentrated urine was confirmed, and a lower urea concentration was demonstrated to be largely responsible for this. Since the V/100 g of hydropenic hypothyroid rats is greater than controls (18) and $U_{\text {urea }}$ is known to depend on $\mathrm{V}(35)$, a comparison of $\mathrm{U}_{\text {urea }}$ and $\mathrm{V}$ was made in control and hypothyroid rats during the saline diuresis. No difference in the renal handling of urea was demonstrated when $U_{u r e a}$ or $C_{u r e a} / C_{i n}$ was compared to $\mathrm{V}$. No explanation for the diminished $\mathrm{U}_{\max }$ in hypothyroid rats is obvious from the present studies, but an alteration in sodium transport by the ascending limb, distal tubular permeability to water, or medullary blood flow seems unlikely since $\mathrm{T}^{\mathbf{c}}{ }_{\mathrm{H}_{2} \mathrm{O}}$ formation is not impaired over a moderate range of diuresis. It may be speculated that hypothyroid rats, even under basal conditions, are undergoing a solute diuresis secondary to an increase in sodium excretion and this in turn causes the lower $U_{\max }$, but the present studies do not permit any firm conclusions to be drawn concerning this defect observed in hypothyroid animals.

The results presented in this report indicate that a certain minimal amount of thyroid hormone is necessary to maintain the maximum sodium reabsorptive capacity of the kidney. Indirect evidence suggests the distal and possibly the proximal tubules are the sites responsible for the diminished sodium reabsorption found in hypothyroid animals.

\section{ACKNOWLEDGMENTS}

We wish to express our appreciation to Doctors R. M. Stein, M. F. Levitt, C. E. Kaufman, and R. B. Thompson for advice in the studies and critical review of the manuscript. We also thank Dr. Martin Goldberg, Associate Professor of Medicine at the University of Pennsylvania for advice in setting up the clearance technique. We are indebted to Dr. Stephen W. Rudich for generous help with the analytical procedures, Mrs. L. Howard for performing the $\mathrm{T}_{3}$ uptake determinations, and Mrs. J. O'Donovan for preparation of the manuscript.

\section{REFERENCES}

1. Fregly, M. J. 1961. Increased water exchange in rats treated with antithyroid drugs. J. Pharmacol. Exp. Ther. 134: 69 .

2. Stephan, F., H. Jahn, P. Reville, and M. Urban. 1961. Effet de l'insuffisance thyroïdienne sur la concentration de l'urée, du sodium et du potassium dans les urines du rat. C. R. Seances Soc. Biol. Filiales. 155: 1555.

3. Stephan, F., H. Jahn, and B. Metz. 1959. Action de l'insuffisance thyroidienne sur l'élimination urinaire de l'eau, du sodium et du potassium chez le rat. C. R. Seances Soc. Biol. Filiales. 153: 332.

4. Taylor, R. E., and M. J. Fregly. 1964. Renal response of propylthiouracil-treated rats to injected mineralocorticoids. Endocrinology. 75: 33.

5. Fregly, M. J., R. L. Brimhall, and O. J. Galindo. 1962. Effect of the antithyroid drug propylthiouracil on the sodium balance of rats. Endocrinology. 71: 693.

6. Fregly, M. J., J. R. Cade, I. W. Waters, J. A. Straw, and R. E. Taylor. 1965. Secretion of aldosterone by adrenal glands of propylthiouracil-treated rats. Endocrinology. 77: 777 .

7. Reville, P., and F. Stephan. 1967. Détermination du gradient intrarénal de concentration de l'urée et du sodium chez des rats hypothyroïdiens et des rats surrénalectomises. C. R. Seances Soc. Biol. Filiales. 161: 174.

8. Krishna, M. S., J. D. Crawford, and M. H. MacGillivray. 1964. Use of the erythrocyte $\mathrm{T}_{{ }^{-}}{ }^{131} \mathrm{I}$ uptake test for evaluating thyroid function in rats. Its application to 
a study of the extrathyroidal action of propylthiouracil. Endocrinology. 74: 415.

9. Porte, A., Y. Fonck-Cussac, P. Stoebner, P. Reville, and F. Stephan. 1966. Etude ultrastructurale du rein chez le rat hypothyroidien. J. Urol. Nephrol. 72: 881.

10. Goldberg, R. C., I. L. Chaikoff, S. Lindsay, and D. D. Feller. 1950. Histopathological changes induced in the normal thyroid and other tissues of the rat by internal radiation with various doses of radioactive iodine. Endocrinology. 46: 72.

11. Buckalew, V. M., M. A. Ramirez, and M. Goldberg. 1967. Free water reabsorption during solute diuresis in normal and potassium-depleted rats. Amer. J. Physiol. 212: 381

12. White, H. L., and D. Rolf. 1957. Whole body and tissue inulin and sucrose spaces in the rat. Amer. J. Physiol. 188: 151

13. Fjeldbo, W., and T. A. Stamey. 1968. Adapted method for determination of inulin in serum and urine with an Autoanalyzer. J. Lab. Clin. Med. 72: 353.

14. Marsh, W. H., B. Fingerhut, and H. Miller. 1965. Automated and manual direct methods for the determination of blood urea. Clin. Chem. 11: 624 .

15. Pitts, R. F. 1963. Physiology of the Kidney and Body Fluids. Year Book Medical Publishers Inc., Chicago, Ill.

16. Snedecor, G. W. 1946. Statistical Methods. Iowa State University Press, Ames. 4th edition.

17. Dixon, W. J., and F. J. Massey. 1957. Introduction to Statistical Analysis. McGraw-Hill Book Company, New York. 2nd edition.

18. Reville, P., F. Stephan, and H. Jahn. 1965. Etude comparative des effets de l'hyperthyroïdisme et de l'hypothyroïdisme sur le débit et la concentration des urines du rat. Arch. Int. Physiol. 73: 97.

19. Reville, P., and F. Stephan. 1968. Etude comparative de la composition du plasma de rats hypothyroïdiens et de rats surrénalectomises. C. R. Seances Soc. Biol. Filiales. $162: 754$.

20. Osorio, J. A., and J. A. Zadunaisky. 1956. Clearances de inulina y diodrast $\mathrm{y}$ peso renal en ratas tratadas con $\mathrm{I}^{131}$ y polvo de tiroides. Rev. Soc. Argent. Biol. 32: 195.

21. Laragh, J. H., and W. G. Kelly 1964. Aldosterone: its biochemistry and physiology. Advan. Metab. Disord. $1: 217$.

22. Cortney, M. A. 1969. Renal tubular transfer of water and electrolytes in adrenalectomized rats. Amer. J. Physiol. 216: 589.

23. Brenner, B. M., and R. W. Berliner. 1969. Relationship between extracellular volume and fluid reabsorption by the rat nephron. Amer. J. Physiol. 217: 6.

24. Schrier, R. W., R. L. Fein, J. S. McNeil, and W. J. Cirksena. 1969. Influence of interstitial fluid volme expansion and plasma sodium concentration on the natriuretic response to volume expansion in dogs. Clin. Sci. (London). 36: 371.

25. Martino, J. A., and L. E. Earley. 1967. Demonstration of a role of physical factors as determinants of the natriuretic response to volume expansion. J. Clin. Invest. 46: 1963

26. Koehn, M. A., W. J. Schindler, and H. C. Stanton. 1967. Thyroid state and vascular reactivity in rats. Proc. Soc. Exp. Biol. Med. 126: 861.

27. Green, K., and A. J. Matty. 1963. Action of thyroxine on active transport in isolated membranes of Bufo Bufo. Gen. Comp. Endocrinol. 3: 244.

28. Marusic, E., and J. Torretti. 1964. Synergistic action of vasopressin and thyroxine on water transfer on the isolated toad bladder. Nature (London). 202: 1118.

29. Sealey, J. E., J. D. Kirshman, and J. H. Laragh. 1969. Natriuretic activity in plasma and urine of salt-loaded man and sheep. J. Clin. Invest. 48: 2210.

30. Barger, A. C. 1966. Renal hemodynamic factors in congestive heart failure. Ann. N. Y. Acad. Sci. 139: 276

31. Horster, M., and K. Thurau. 1968. Micropuncture studies on the filtration rate of single superficial and juxtamedullary glomeruli in the rat kidney. Pfuegers Arch. $301: 162$.

32. Jahn, H., P. Reville, and F. Stephan. 1964. Action de l'insuffisance thyroïdienne chronique sur la concentration osmolaire totale et la concentration de sodium des urines du rat au cours de la polyurie osmotique par le mannitol. Rev. Fr. Etud. Clin. Biol. 9: 181

33. Malnic, G., R. M. Klose, and G. Giebisch. 1966. Microperfusion study of distal tubular potassium and sodium transfer in rat kidney. Amer. J. Physiol. 211: 548.

34. Giebisch, G., R. M. Klose, and E. E. Windhager. 1964. Micropuncture study of hypertonic sodium chloride loading in the rat. Amer. J. Physiol. 206: 687.

35. Shannon, J. A. 1936. Glomerular filtration and urea excretion in relation to urine flow in the dog. Amer. J. Physiol. 117: 206. 